\section{Holub H., \\ Kulbovskyi I., Skliarenko I., Bambura 0., Tkachuk $M$.}

\title{
RESEARCH OF METHODS FOR IDENTIFICATION OF EMERGENCY MODES OF POWER SUPPLY SYSTEM IN TRANSPORT INFRASTRUCTURE PROJECTS
}

Об’єктом дослідження є режими роботи системи електропостачання залізничного транспорту. Класичною є класифікація аварійних режимів, що грунтується на визначенні пошкодження по кожному з фідерів або фаз. До основних причин аварійних режимів відносять різного роду короткі замикання, що виникають внаслідок пошкодження ізолящї фаз, обривів та перенапруг. Пошкодження обладнання відбувається із-за природного старіння ізолящї, атмосферних впливів або механічних пошкоджень, комутаційнх перенапруг.

В ході дослідження використовувалися системний підхід, методи системного аналізу, теорії множин, сучасні методи обробки зображень та інтелектуальної обробки даних, із забезпеченням властивостей масштабованості розроблюваних методів.

Досліджено методи для алгоритмічних рішень та представлені математичні моделі обробки та організацї інформачійного простору, представленого множинами багатовимірних масивів даних з прив'язкою до часової області, яка формується на ієрархічних рівнях корпоративної комп'ютерної системи діагностики. Розглядуваний інформаційний простір у вихідному виді утворює дані, які розглядаються у якості параметричних зображень процесів, отримувані від мікропроцесорних пристроїв реєстрації параметрів систем. Це пов'язано з тим, що методи ідентифікації аварійних режимів електроенергетичних систем на основі відповідних параметричних зображень процесів дозволяють отримувати схожі за структурою алгоритми ідентифікації режимів для енергосистем різного типу та призначення.

Завдяки цьому забезпечується попередня обробка даних для зведення параметричного зображення аварійного режиму до стандартної форми матричного представлення у частотній області. У порівнянні з аналогічними методами, ие забезпечує такі переваги, як можливість роботи системи діагностики як в «off-line», так $i$ в «оn-line» режимах. А реалізація алгоритмічних рішень може бути забезпечена як на нижньому рівні систем діагностики, так $і$ на верхніх рівнях ділянок електропостачання, а також на корпоративному рівні і характеризуватися властивостями масштабованості та гнучкості відносно розглядуваних ділянок енергосистем.

Ключові слова: алгоритми ідентифікацї режимів, система електропостачання залізничного транспорту, комп'ютерні системи, інформаційний простір.

Received date: 11.06.2019

Accepted date: 04.07.2019

Published date: 31.10 .2019
Copyright (C) 2019, Holub H., Kulbovskyi I., Skliarenko I., Bambura O., Tkachuk M. This is an open access article under the CC BY license (http://creativecommons.org/licenses/by/4.0)

\section{Introduction}

The present dictates new conditions for the efficient operation of power supply systems, providing for reliable and uninterrupted power supply. Cases of violation of the normal operating modes of the system are considered as accidents or abnormal modes, depending on the nature of their course, the degree of equipment damage and consequences. The main task of the operational dispatch control of the modes of systems and its energy facilities is to ensure constant monitoring of the parameters of the regime, as well as predicting possible unacceptable changes in the operation of systems. Based on the values of the parameters of the modes, the operational identification of the state is carried out with the aim of forming control actions for the redistribution of energy flows, preventing the occurrence or localization of emergency situations [1]. It is worth noting that in real operating conditions, the power supply system of the railway is fully equipped with the necessary monitoring systems and is not fully automated, which complicates the task of recognizing the mode of electric networks. With the development of computer and intelligent technologies, the level of automation in the management of systems and objects is growing. In this case, the identification of modes is solved by intelligent computer systems, which, for the implementation of the necessary functionality, processing data from geographically distributed energy facilities [2].

The experience of scientists [3-5] shows that the approaches and methods for identifying emergency conditions of the power supply system allow to obtain good accuracy and efficiency at the lower levels of the hierarchy of the system. But they do not allow to generalize the results of development and transfer relevant information to higher levels of the hierarchy of the system.

At present, solving identification problems is of great scientific and practical value precisely at system levels [6]. 
Therefore, it is urgent to combine data from various registrars and other monitoring devices, process significant volumes of information and synchronize and systematize it. In this case, the object of research is the operating modes of the railway transport power supply system. And the aim of research is studying methods for identifying emergency modes of the power supply system for their parametric images, based on set theory, modern image processing methods and intelligent data processing, ensuring the scalability of the developed methods and the unification of identification algorithms. At the same time, the desired properties are achieved by an effective target combination of these approaches and theoretical principles.

\section{Methods of research}

The solution to the problem of identifying emergency conditions lies in the field of a certain classification system, covering the full range of possible situations, and is a methodological basis for the application of preventive, liquidation and repair measures. In addition, the results of the operational determination of the location of damage depend on the reliability of the results of identification of emergency conditions. Moreover, data mining plays a fundamental role in the development of modern systems, namely, the railway power supply system [7]. The main problems, first of all, should include the selection of useful information from the available recorded data - parameters of voltage currents of modes or from data obtained in real time.

The railway power supply system is characterized by specific structural and parametric features, it is characterized by significant transient conditions, as well as «moving loads». Therefore, the tasks of determining the type and location of damage are more complex compared to generalpurpose power systems, and are also complemented by increased requirements for the efficiency of finding the location of damage.

\section{Research results and discussion}

To identify the accident in each set, a minimum basis of parameters is allocated, which is sufficient for identification. For a comprehensive solution to the problem of identifying emergency modes of establishing the causes of accidents, identifying abnormal conditions, and also realizing the possibility of preventive control, it is necessary to process information on analog signals characterizing the operating modes of the system [8].

Developed emergency recognition algorithms should carry out «on-line» or (and) «off-line» identification taking into account the values and dynamics of changes in the parameters of the mode, type of power supply system and configuration of the electric network [9].

For a formalized representation of emergency mode, let's accept the following notation:

$A=\left\{A_{i}\right\}-$ set of emergency conditions that may occur in the system;

$A_{c}$ - set of emergency conditions that occurred and were perceived by the system;

$A_{n}$ - set of emergency conditions that have not yet occurred.

Based on these notations, the set of emergency modes $A$ is the union of two intersecting subsets that can occur in a system which mathematical model:

$$
A=A_{c} \cup A_{n}
$$

Emergency modes that belong to the set $A_{c}$, when reoccurring, are identified by the system. Elements of a set of emergency modes $A_{n}$ can also be recognized by the system if their characteristics are known in advance.

Each emergency mode $A_{i}$ is represented by a set of time-variable parameters or a set of signals, which can be considered a parametric image of the mode.

Since simple methods of logical conditions and conclusions can be used to process a plurality of discrete signals, within the framework of this work, only a plurality of analog signals are accepted for identification of emergency conditions [10].

Thus, for an arbitrary emergency mode, it is possible to record:

$$
A_{i}=\left\{u_{j}^{i}(t)\right\}, 0 \leq t \leq T
$$

where $u_{j}^{i}(t)$ - the amplitude of the analog $j$-th signal $(j=1 . . m, m-$ the number of signals characterizing the accident) of the $i$-th accident at time $t ; T-$ the duration of the emergency mode.

The change in the $j$-th analog signal during emergency mode $T$ is characterized by an array of signal values $u_{j}^{i}(t)$ in the time domain:

$$
u_{j}^{i}(t)=\left\{u_{j}^{i}\left(t_{1}\right), u_{j}^{i}\left(t_{2}\right), \ldots, u_{j}^{i}(T)\right\} .
$$

That is, each emergency mode can be submitted as:

$$
A_{i}=\bigcup_{j} u_{j}^{i}(t)
$$

The whole set of possible emergency modes (1) is characterized by changes in analog signals. In this case, the subsets of accidents with a common set (1) are characterized by the same subsets of signals (2). For this reason, the emergency mode identification process can be shortened by identifying common features. To reduce the identification time, a common set of parameters for all emergency modes is determined according to the expression:

$$
A_{r}=\bigcap_{i} A_{i} .
$$

If $A_{r}=\{\varnothing\}$, then a search is made for emergency modes that have common parameters by which the group is determined for further identification. Under real operating conditions, it is impossible to describe all emergency modes $A_{n}$, the sets $A_{c}$ are subject to a description and the system sequentially learns with the onset of a new emergency mode. According to the given conditions and judgments, the total set of parameters that is determined depends on the operating time of the system. The process of determining the set of parameters $A_{r}(t)$ is carried out constantly with the arrival of the parameters of each new emergency mode:

$$
A_{r}\left(t_{l+1}\right)=A\left(t_{l+1}\right) \cap A_{r}\left(t_{l}\right),
$$

where $A\left(t_{l+1}\right)$ - the set of parameters of the new emergency mode, arrived at time $t_{l+1} ; A_{r}\left(t_{l}\right)$ - the set obtained as a result of crossing (5) at time $t_{l}$.

$$
A_{r}^{1}\left(t_{l}\right)=A_{r}\left(t_{l+1}\right) \leq A_{r}\left(t_{l}\right) .
$$


Thus, the first set $A_{r}^{1}(t)$ is formed, obtained by crossing the sets of parameters of the regimes completed.

If as a result of (7) there will be an empty set:

$$
A_{r}\left(t_{l+1}\right)=\{\varnothing\},
$$

then

$$
A_{r}\left(t_{l+2}\right)=A\left(t_{l+2}\right) \cap A_{r}\left(t_{l}\right),
$$

the second set of sections begins to form.

The search for the emergency mode is carried out, the set of parameters of which give a non-empty intersection with the set of this emergency mode, while the process of forming the set $A_{r}^{2}(t)$, like the set $A_{r}^{1}(t)$, is continuous. With the arrival of the parameters of the new emergency mode $A_{i}\left(t_{l+p}\right)$, for which the following relationships are true:

$$
\left\{\begin{array}{l}
A_{i}\left(t_{l+p}\right) \cap A_{r}^{1}\left(t_{l}\right)=\{\varnothing\}, \\
A_{i}\left(t_{l+p}\right) \cap A_{r}^{2}\left(t_{l}\right)=\{\varnothing\},
\end{array}\right.
$$

a new common set begins to form by determining intersections with other sets of emergency conditions that took place.

Thus, when identifying in real time, the set are constantly being formed:

$$
A_{r}^{\Sigma}(t)=\left\{A_{r}^{i}(t)\right\} .
$$

All elements of the set (11) change in time and the process of change occurs with the arrival of a new emergency mode, which has not yet taken place for the entire duration of the system.

To speed up the identification process, a distribution of the elements of the set $A_{r}^{\Sigma}(t)$ is carried out according to the number of emergency conditions covered by the most common characteristic that are assigned to them. With the arrival of analog signals indicating the emergency mode, which took place for the first time, set of parameters are formed for subsequent comparison with the elements of the set $A_{r}^{\Sigma}(t)$. Moreover, the elements of the set (11) are arranged in sequence in descending order of the number of elements of the set.

$$
A_{r}^{1}(t)>A_{r}^{2}(t)>\cdots>A_{r}^{n}(t)
$$

So, first the first set is compared, by determining the cross section and, accordingly, the emergency mode in the existing ones:

$$
A_{i}\left(t_{l+1}\right)=\left\{\begin{array}{l}
1, \text { at } A_{i}\left(t_{l+1}\right) \cap A_{r}^{1}\left(t_{l}\right)=A_{r}^{1}\left(t_{l}\right), \\
0, \text { in other cases. }
\end{array}\right.
$$

The one indicates that $A_{i}\left(t_{l+1}\right)$ belongs to the group of emergency modes that form, zero indicates the need for comparison with the subsequent set $A_{r}^{2}(t)$. Thus, the definition of the group to which the emergency mode belongs is carried out by the formation of the set:

$$
A_{i}\left(t_{l+1}\right)=\left\{\begin{array}{l}
A_{r}^{k}\left(t_{l}\right), \text { at } A_{i}\left(t_{l+1}\right) \cap A_{r}^{k}\left(t_{l}\right)=A_{r}^{k}\left(t_{l}\right), \\
0, \text { in other cases, }
\end{array}\right.
$$

where $k$ - the pointer to the group of accidents which intersection sets gives $A_{r}^{k}(t)$.

\section{Conclusions}

The methodology for constructing generalized classification systems for emergency modes for use in computer systems for diagnosing railway traction power systems is analyzed.

Methods of identification of emergency modes of the railway power supply system are investigated, which allow identifying modes that allow building solutions that have the desired scalability, adaptability and flexibility regarding the structure of the diagnosed power systems.

\section{References}

1. Kulbovskyi, I., Sapronova, S., Holub, H., Tkachenko, V., Afanasieva, I., Safronov, O. (2019). Development of a Model for Managing the Quality of Repair and Maintenance of Rolling Stock in Transport Infrastructure Projects. Transport means, 201-206.

2. Stasiuk, O. I., Butkevych, O. F., Levkoniuk, A. V. (2014). Pidvyshchennia nadiinosti monitorynhu dopustymosti zavantazhen kontrolovanykh peretyniv enerhosystem. Tekhnichna elektrodynamika, 2, 56-67.

3. Kachesov, V. E., Kvrivishvili, L. V. (2008). Raspoznavanie odnofaznogo dugovogo zamykaniia na zemliu i povrezhdennoi fazy v raspredelitelnykh setiakh s izolirovannoi neitraliu. Nauchnye problemy transporta Sibiri i Dalnego vostoka, 1, 94-98.

4. Gayathri, K., Kumarappan, N. (2010). Accurate fault location on EHV lines using both RBF based support vector machine and SCALCG based neural network. Expert Systems with Applications, 37 (12), 8822-8830. doi: http://doi.org/10.1016/j.eswa.2010.06.016

5. Kyrylenko, O. V., Blinov, I. V. (2008). Vyznachennia mists poshkodzhen na liniiakh elektroperedachi z vykorystanniam shtuchnykh neironnykh merezh. Elektrotekhnika i enerhetyka, 8, 9-12.

6. Kalyniuk, I. O. (2012). Analiz parametriv neshtatnykh rezhymiv v elektrychnykh merezhakh zaliznytsi. Zaliznychnyi transport: suchasni problemy nauky. Kyiv: DETUT, 1, 26-27.

7. Stasiuk, O. I., Honcharova, L. L., Maksymchuk, V. F. (2012) Metody orhanizatsii kompiuternoi merezhi monitorynhu parametriv rezhymiv system elektropostachannia. Informatsiino-keruiuchi systemy na zaliznychnomu transporti, 2, 35-40.

8. Kulbovskyi, I. I., Holub, H. M, Kyiashko, V. T., Andonova, S. (2018). Information model of railway transport power supply system computer monitoring data flow. Metallurgical and Mining Industry, 2, 31-36.

9. Bilan, S. M., Motorniuk, R. L., Voronko, I. O. (2012). Prohramne zabezpechennia dlia identyfikatsii avariinykh rezhymiv elektroenerhetychnykh systemakh na osnovi spektralnykh kharakterystyk. Teoriia pryiniattia rishen. Uzhhorod, 31-32.

10. Stasiuk, O. I., Tutyk, V. L., Honcharova, L. L., Holub, H. M. (2015). Matematychni modeli i kompiuterno-oriientovani metody monitorynhu i identyfikatsii avariinykh rezhymiv tiahovykh merezh. Informatsiino-keruiuchi systemy na zaliznychnomu transporti, 2, 7-13.

Holub Halyna, PhD, Associate Professor, Department of Automation and Computer-Integrated Technologies of Transport, State University of Infrastructure and Technologies, Kyiv, Ukraine, ORCID: http:// orcid.org/0000-0002-4028-1025, e-mail: golub.galina@ukr.net

Kulbovskyi Ivan, PhD, Associate Professor, Department of Automation and Computer-Integrated Technologies of Transport, State University of Infrastructure and Technologies, Kyir, Ukraine, ORCID: http:// orcid.org/0000-0002-5329-3842,e-mail: kulbovskiy@ukr.net

Skliarenko Inna, PhD, Associate Professor, Senior Researcher Research Sector, State University of Infrastructure and Technologies, Kyiv, Ukraine, ORCID: http://orcid.org/0000-0002-1428-1793, e-mail: innakdavt@ukr.net

Bambura Olga, PhD, Department of Theoretical and Applied Mechanics, State University of Infrastructure and Technologies, Kyiv, Ukraine, ORCID: http://orcid.org/0000-0002-8602-5086, e-mail: Bambura_olja@ukr.net

Tkachuk Mykola, Head of Department, Technical Department of the Signaling and Communication Service Russian Federation «Southwestern Railway», Regional Branch «South-Western Railway» of JSC «Ukrzaliznytsia», Kyiv, Ukraine, ORCID: http://orcid.org/00000002-9683-4303,e-mail: tkachuk@sw.uz.gov.ua 